\title{
Progress in the biological control of Argentine stem weevil and comment on its potential
}

\author{
S.L. GOLDSON ${ }^{1}$, G.M. BARKER ${ }^{2}$, B.I.P. BARRATT ${ }^{3}$ and N.D. BARLOW' \\ ${ }^{1}$ AgResearch Lincoln, PO Box 60, Lincoln \\ ${ }^{2}$ AgResearch Ruakura, Private Bag 3123, Hamilton \\ ${ }^{3}$ AgResearch Invermay, Private Bag 50034, Mosgiel
}

\begin{abstract}
Between 1988 and 1990 three visits were made to South America to search for and collect the Argentine stem weevil parasitoid Microctonus hyperodue. This resulted in the importation of 240 parthenogenetic parasitoid lines collected from seven very different ecoclimatic zones. Each zone was assumed to have resulted in a corresponding 'ecotype'. Throughout the winter of 1991,100 000 parasitised weevils were liberated at selected sites in the northern North Island, northern South Island and Otago/Southland. During this work, care was taken to rear and release the parasitoid ecotypes in equal numbers. In this way establishment patterns of the different ecotypes in different climate zones should eventually be able to be established thereby giving new insights into the importance of parasitoid preadaptation in achieving biological control. Since its release, detailed research has been conducted into the spread and build up of Microctonus hyperodue. In most places, especially in the north,-the-parasitoid-has-established-and built up to high levels of parasitism $(80 \%)$ with unexpected rapidity, although its rate of spread has been modest at around 1-3 km p.a. Preliminary results from both Canterbury and the northern North Island indicate that the pest potential of Argentine stem weevil population has already been substantially reduced in its release areas.
\end{abstract}

Keywords: Argentine stem weevil, biological control, dispersal rate, Microctonus hyperodae, percent parasitism,

\section{Introduction and background}

Argentine stem weevil (Listronotus bonariensis (Kuschel)) is New Zealand's worst ryegrass pest and was first recorded in New Zealand in about 1927 (Marshall 1937). Prestidge et al. (1991) have estimated that the species costs the nation between $\$ 78-251 \mathrm{M}$ p.a. through damage to pasture. In particular, the tillermining larval stage causes insidious damage which is often manifested by lack of recovery of ryegrass pasture after summer drought (e.g. Whatman 1959) and/or change in composition to clover or weed dominance (e.g. May 1961). L. bonariensis damages many pasture species and cereal crops and is particularly severe in short rotation stands (Lolium multiflorum) (e.g. Kelsey 1958) which have useful cool-season characteristics.

There have been ongoing efforts to control $L$. bonariensis in established pasture using insecticides (e.g. Pottinger et al. 1984). However, the development of practical solutions has been thwarted by the species' high reproductive potential, the sheltered stem-mining habit of its larvae and the weevils' unpredictable and sometimes large dispersal flights (particularly in dry east coast areas) (e.g. Pottinger 1966; Goldson 1981). Additionally there has been growing awareness of the potentially adverse effects of insecticidal treatment necessary to give season-long control. Conversely, however, systemic insecticide treatment at sowing (as granular formulations or through insecticidally treated seed) has been shown to usefully increase establishment by protecting the emerging cotyledons (Trought 1976; Barker et al. 1990; Addison $\boldsymbol{e t}$ al. 1993); such use is now_routine among some farmers to enhance seedling establishment.

In view of the limited value of pesticides against $L$ bonariensis, there has been considerable attention paid to the potential of grass resistance. As early as the 1950s the higher susceptibility of short rotation ryegrasses (Lolium multiflorum L.) than perennial ryegrass (Lolium perenne L.) to L. bonariensis was noted (e.g. Kelsey 1958). This was later quantified by Timlin (1964) who found that $84 \%$ of the L. multiflorum tillers were attacked in mature crops compared with $35 \%$ inperennial-stands, These-early observationswere later extended to an analysis of the factors that influence such differential susceptibility. Goldson (1982) noted that the susceptibility of hybrid ryegrasses $(L$. perenne $x$ L. multiflorum crosses) to $L$. bonariensis appeared to be related to the amount of $L$. multiflorum in the cultivar's genotype. In comparing these results to those obtained from non Lolium grass species, Goldson (1982) hypothesised that ovipositional preference appeared to be related at least in part to stem 'toughness'. It was also noted that oviposition rarely occurred on tillers of $<0.5 \mathrm{~mm}$ diameter (Goldson 
unpublished data). These findings were later supported by Barker (1989) who, working with a wider range of grass species, found that weevil preference was correlated with tiller fibre and silica content in addition to soluble carbohydrates. The importance of tiller diameter has been confirmed by Pilkington (1989).

In the early 1980s the link between endophyte infection and weevil attack was observed and quantified (Prestidge et al. 1982; Barker et al. 1983). Prior to this, attempts to identify and breed for plant resistance against $L$. bonariensis in ryegrass was inevitably strongly influenced by the extent to which plants were variably infected by the endophyte fungus Acremonium lolii Latch, Christensen and Samuels. Associated with this discovery Barker $\boldsymbol{e t}$ al. (1989) in the Waikato were later able to relate the $L$. bonariensis carrying capacity of pasture to the available non-endophytic tiller resource. As a result, much of current management practice depends on the establishment of pastures using $A$. lo\&infected ryegrass seed.

Just prior to the discovery of endophyte associated resistance to $L$. bonariensis, it was demonstrated that A. lolii was also implicated in ryegrass staggers (Fletcher \& Harvey, 1981; Gallagher et al. 1981). through the fungal metabolite lolitrem. As a result, considerable effort has since been invested in developing $A$. lolii-infected plants that retain their activity against $L$. bonuriensis but have minimal adverse effects against livestock. However, this work has recently shown that the situation is considerably more complex than it initially appeared with a range of endophyte-associated biochemical effects impacting on livestock health and production (e.g. Fletcher 1993). Partly because of this complexity, there have also been continuing efforts to define genetic resistance in A. lolii-free perennial ryegrass (e.g. Easton \& Popay 1990; Prestidge $e t$ al. 1992). Related to the overall question of $L$. bonariensis/host plant interaction, it is intriguing to note that the species' association with Lolium spp. is novel. Primitively, the genus Listronotus is thought to be associated with Graminae such as Pou and Deyeuxia spp. found in stream-fed swampy areas resembling cushion bogs and flush vegetation swamps in New Zealand (S. Halloy, pers. comm.).

L. bonuriensis apparently established in New Zealand without its suite of natural enemies. Classical biological control therefore offers the potential for an ideally complementary approach to grass resistance described above. Moreover, it has been noted that there can be synergy between plant resistance and biological control (e.g. van Emden 1982).

Attempts at biological control of $L$. bonariensis were first made in the 1960s by the DSIR when the egg parasitoid Patasson (= Anaphes) atomarius (Brethes) and an unknown larval parasitoid were released in New Zealand. Both failed to establish (Dymock 1989). The intent of the Resource Management Act 1990 has since demanded host specificity amongst biological control agents in order to protect non-target species. Partly because of this need for oligophagy, attention in the late 1980s was directed towards the braconid parasitoid wasp Microctonus hyperodue Loan first described by Loan \& Lloyd (1974). Species of this genus are thought to be generally oligophagous (Loan 1969, 1975). During an initial visit to South America in 1988, far higher levels of parasitism (e.g. 77\% in Chile, Goldson et al. 1990) were encountered than initially expected, based on Loan \& Lloyd (1974) and Lloyd's unpublished CIBC reports. Consequently between 1989-90 seven presumed ecotypes of $M$. hyperodue were imported into New Zealand quarantine from Brazil, Uruguay, Argentina and Chile (Goldson et al. 1990). Host range testing showed a degree of oligophagy sufficient for permission to be granted for the parasitoid's release (Goldson et al. 1992). Accordingly, during the winter of 1991, 100 000 parasitoids were reared and released in the northern North Island, Canterbury and Otago/Southland (Goldson et al. 1994). Rearing was conducted in such a way that equal numbers of each ecotype were produced and released. On this basis it is hoped to eventually measure the importance of pre-adaptation in biological control and define what characteristics confer advantage.

\section{Parasitoid establishment}

To date $M$. hyperodue has been recovered from all of its release sites except two of the four localities in the Otago/Southland region. Detailed study of the wasp's population increase has been made in the northern North Island, Canterbury and Otago/Southland. With the exception of the latter region, the rate of build up has exceeded expectation. In the northern North Island the progeny of the parasitoids released in the winter of 1991 were recovered as early as 11 October 1991 (Goldson et al. 1994). Thereafter the rate of parasitism increased rapidly with autumnal peaks of $26-36 \%$ in

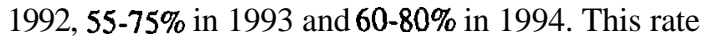
of build up is consistent with the three parasitoid generations predicted by Barlow et al. (1995). Conversely, in Canterbury, parasitoid build up has been slower because of the cooler conditions. Phenological modelling has indicated two generations per year (Barlow et al. 1995). The first M. hyperodue recovery was made on 8 January 1992 (Goldson et al. 1994); this built up and peaked at $48.3 \%$ in April 1993. During the second season parasitism peaked at 79\% in March 1994. In Otago the establishment build up has been even slower; the first recovery was made at Ophir on 1 
October 1992 and (possibly) at Sutton on 14 February 1993. Parasitism has not exceeded $13 \%$ in either location.

Of more importance than peak parasitism, however, is its timing. In the northern North Island, analysis has indicated that in perennial pasture the summer generation of weevils is the most damaging (Barker $\boldsymbol{e} t$ al. 1981) because overwintering survival in the moist northern areas is limited by disease, particularly Beauveria bassiana (Balsamo) (Barker et al. 1989). Consequently, summer parasitism rates are particularly important. Preliminary analyses of ASW life tables indicate that at the parasitism levels achieved in the 1993-94 season, the parasitoid has significantly reduced the damaging larval populations (Barker, unpublished data).

In Canterbury, overwintering survival of $L$. bonariensis is much higher than in the north (Barker et al. (1981); Goldson \& Proffitt unpublished data). This therefore results in the spring larval populations being more damaging and overwintering parasitism levels are therefore particularly important. It is significant that by March 1994, 79\% of the population was infected (Goldson and Proffitt unpublished data) and the ground population at the release site had dropped to $24 / \mathrm{m}^{2}$ (as opposed to a mean autumnal population of c. $220 / \mathrm{m}^{2}$ taken over the 1991, 1992 and 1993 seasons). Again this development looks most promising.

While in both the North and South Islands these results are very encouraging, there remains the need to research a range of other facets such as the ability of the weevil population to compensate for high mortality in one of its life stages.

In addition to parasitising and sterilising the weevils, the parasitoid may have effects other than those directly attributable to parasitism. It has been observed that parasitism greatly increases the vulnerability of $\boldsymbol{L}$. bonariensis to B. bassiana (Barker \& Goh 1992) and that in cages at least, the mere presence of the parasitoid increased weevil mortality (Goldson et al. 1993). Recently it has been similarly observed that ovipositional effort appeared to decline in the parasitoid's presence (Barratt unpublished data). At the very high parasitoid densities sometimes observed in the field there is evidence that these unexplained effects are also having an impact (Goldson \& Proffitt unpublished data).

In contrast to such rapid parasitoid build up at the release sites, the species' rate of dispersal has to date been relatively slow. Two and a half years after release at Lincoln it was found to have dispersed a maximum of about $7 \mathrm{~km}$ (Goldson unpublished data) and $3 \mathrm{~km}$ at the North Island release sites (Barker unpublished data).

\section{Outlook}

Given that it is only 3 years since the parasitoid's liberation, the high rate of $L$. bonariensis parasitism and its (albeit) slow dispersal indicate that the outlook for $\boldsymbol{M}$. hyperodue as an effective control agent is good. However, the weevil's population behaviour in the dry East Coast and Otago regions is still very poorly understood, particularly its ability to compensate for parasitism.

Generally, there now seems to be little doubt that in many regions within New Zealand, the parasitoid will become a major component of IPM systems using endophyte and other resistant grasses. These interactions have yet to be studied in any detail and current research is now strongly orientated in that direction.

\section{REFERENCES}

Armstrong, C.S. 1977. 'Grassland Nui' perennial ryegrass. New Zealand journal of experimental agriculture 5: 381-384.

Barker, G.M.; Pottinger, R.P.; Addison P.J.' 1981. Argentine stem weevil in northern North Island pastures. Proceedings of the 33rd Ruakura Farmers' Conference: 85-89.

Barker, G.M.; Pottinger, R.P.; Addison P.J. 1989. Population dynamics of Argentine stem weevil (Listronotus bonariensis) in pastures of Waikato, New Zealand, Agricuture, ecosystems and environment 26: 79-11.5.

Barker, G.M.; Goh. H.H. 1992. Interactions between the parasitoid Microctonus hyperodae and the pathogen Beauveria bassiana in the Argentine stem weevil, Listronotus bonariensis. pp 272-274. In: Corey, S.A.; Dall D.J.; Milne, W.M. (eds.). Pest Control and Sustainable Agriculture. CSIRO Australia.

Barlow, N.D.; Goldson, S.L.; McNeill, M.R. 1995. A prospective model for the phenology of Microctonus hyperodae (Hymenoptera: Braconidae), a potential biological control agent of Argentine stem weevil in New Zealand. Biocontrol science \& technology: (in press).

Dymock, J.J. 1989. Listronotus bonariensis (Kuschel), Argentine stem weevil (Coleoptera: Curculionidae). pp 23-26. In: Cameron, P.J.; Hill, R.J.; Bain, J.; Thomas, W.P. (eds.). A Review of Biological Control of Invertebrate Pests and Weeds in New Zealand 1874-1987. CAB International Institute of Biological Control.

Fletcher, L.R. 1993. Grazing ryegrass/endophyte associations and their effect on animal health and performance. Proceedings of the Second Inter. 
national Symposium on Acremonium/Grass Interactions: plenary papers: 11 5- 120.

Fletcher, L.R.; Harvey, I.C. 1981. An association of Lolium endophyte with ryegrass staggers. New Zealand veterinary journal 29: 185- 186.

Gallagher, R.T.; White, E.P.; Mortimer, P.H. 1981. Ryegrass staggers: Isolation of potent neurotoxins Lolitrem A and Lolitrem B from staggers-producing pastures. New Zealand veterinary journal 29: 189190.

Gaynor, D.L.; Rowan, D.D. 1985. Peraniine - an Argentine stem weevil feeding deterrent from endophyte-infected ryegrass. Proceedings of the fourth Australasian Conference on Grassland Invertebrate Ecology: 338-343.

Goldson, S.L. 1981. Non-reproductive determination of 'migratory' flight in Argentine stem weevils. Physiological entomology 6: 283-288.

Goldson, S.L. 1982. An examination of the relationship between Argentine stem weevil Listronotus bonariensis (Kuschel) and several of its host grasses. New Zealand journal of agricultural research 25: 395-403.

Goldson, S.L.; McNeill, M.R.; Stufkens, M.W.; Proffitt, J.R.; Pottinger, R.P.; Farrell, J.A. 1990. Importation and quarantining of Microctonus hyperodae a South American parasitoid of Argentine stem weevil. Proceedings of the 43rd New Zealand Weed and Pest Control Conference: 334-338.

Goldson, S.L.; McNeill, M.R.; Phillips, C.B.; Proffitt, J.R. 1992. Host specificity testing and suitability of the parasitoid Microctonus hyperodae Loan (Hymenoptera: Braconidae, Euphoiinae) as a biological control agent of Listronotus bonariensis (Kuschel) (Coleoptera: Curculionidae) in New Zealand. Entomophaga 37: 483-498.

Goldson, S.L.; McNeill, M.R.; Proffitt, J.R. 1993. Unexplained mortality amongst unparasitised Listronotus bonariensis in the presence of the parasitoid Microctonus hyperodae under caging conditions. Proceedings of the 6th Australasian Conference on Grassland Invertebrate Ecology: 355-362.

Goldson, S.L.; McNeill, M.R.; Proffitt, J.R.; Barker, G.M.; Addison, P.J.; Barratt, B.I.P.; Ferguson, CM. 1994. Systematic mass rearing and release of Microctonus hyperodae Loan (Hym.: Braconidae, Euphorinae), a parasitoid of the Argentine stem weevil Listronotus bonariensis (Kuschel) (Col.: Curculioniae) and records of its establishment in New Zealand. Entomophaga 38: (in press).

Kelsey, J.M. 1958. Damage in ryegrass by Hyperodes griseus Hust. New Zealand journal of agricultural research 1: 790-795.
Loan, C.C. 1969. A summary of species of Microctonus north of Mexico with five new species. Proceedings of the Entomological Society of Washington 70: 404-416.

Loan, C.C. 1975. A review of the Haliday species of Microctonus (Hymenoptera: Braconidae, Euphorinae). Entomophaga 20: 31-41.

Loan, C.C.; Lloyd, D.C. 1974. Description and field biology of Microctonus hyperodae Loan n. sp. (Hymenoptera: Braconidae, Euphorinae) a parasite of Hyperodes bonariensis in South America (Coleoptera: Curculionidae). Entomophaga 19: 7 12.

Marshall, G.A.K. 1937. New Curculionidae collected from New Zealand. Transactions of the New Zealand Institute 67: 316-340.

May, B.M. 1961. The Argentine stem weevil, Hyperodes bonariensis (Kuschel) on pasture in Auckland. New Zealand journal of agricultural research 4: 289. 297.

Kain, W.M.; Richie, I.M.; Crouchley, C.G.; Smith, R.G.; Atkinson, D.S. 1977. Effects of stem weevil on grazed swards of perennial ryegrass in Wairarapa and Manawatu. Proceedings of the 30th New Zealand Weed and Pest Control Conference: 192197.

Pottinger, R.P. 1966. Observations on the flight activity of stem weevil Hyperodes bonariensis Kuschel in Canterbury. Proceedings of the 19th New Zealand Weed and Pest Control Conference: 186-196.

Pottinger, R.P.; Barker, G.M.; Wrenn, N.R.; Addison, P.J.; McGhie, R.A. 1984. Insecticidal control of adult Argentine stem weevil: a review and bioassay evaluations. Proceedings of the 37th New Zealand Weed and Pest Control Conference: $101,105$.

Prestidge, R.A.; Barker, G.M.; Pottinger, R.P. 1991. The economic cost of Argentine stem weevil in pastures in New Zealand. Proceedings of the 44th New Zealand Weed and Pest Control Conference: 165-170.

Timlin, J.S. 1964. Diagnosis and extent of damage by the stem weevil. Proceedings of the 17th New Zealand Weed and Pest Control Conference: 149151.

Trought, T.E.T. 1976. Control of Argentine stem weevil in seedling ryegrass. Proceedings of the 29th New Zealand Weed and Pest Control Conference: 6062

van Emden, H.F. 1982. Principles of implementation of IPM. In: Cameron, P.J.; Wearing, C.H.; Kain, W.M. (eds): Proceedings of Australasian Workshop on Development and Implementation of IPM: 9-17. 